International Journal of English Literature and Social Sciences
Vol-6, Issue-1; Jan-Feb, 2021

\title{
Intertextual: Novel Bumi Manusia by Pramodya Ananta Toer and Novel Sang Raja by Iksaka Banu
}

\author{
Nungki Dwi Rahayu ${ }^{1}$, Suyitno $^{2}$, Nugraheni Eko Wardani ${ }^{3}$
}

Postgraduate Program of Indonesia Language Education, Universitas Sebelas Maret, Surakarta, Indonesia

Received: 29 Oct 2020; Received in revised form: 14 Jan 2021; Accepted: 30 Jan 2021; Available online: 19 Feb 2021

(C2021 The Author(s). Published by Infogain Publication. This is an open access article under the CC BY license

(https://creativecommons.org/licenses/by/4.0/).

\begin{abstract}
This study aims to describe the intertextual of Novel Bumi Manusia by Pramodya Ananta Toer and Novel Sang Raja by Iksaka Banu. This research used a descriptive qualitative method; it described the results of the analysis in words or sentences. Data collection used note-taking and documentary techniques by recording quotes or sentences in the text of the novel. The analysis technique used qualitative analysis described the analysis results in sentences, not in numbers. The data validation used two techniques. The first technique was the observer's persistence to probe deeper into the analysis results to acquire more accurate results. And the second technique was triangulation; it was not using only one view but also several views to get the right result. The results found that there were similarities between the novel Bumi Manusia and Sang Raja. They had similarities in terms of themes, namely about the struggle in the colonial period. The second similarity was the characterization, where there was a similarity in the main character's setting, while the additional characters appeared to have the same characteristics. The third similarity could be seen in the setting, the situation experienced by the main character of both novels was sadness. So it could be concluded that the novel Bumi Manusia was a hypogram text, and Sang Raja was a transformation text.
\end{abstract}

Keywords - hypogram, intertextual, literary, transformation.

\section{INTRODUCTION}

Literary works are formed from humans' creative activities to express their appreciation and taste and are expressed by using language. Appreciation can occur while enjoying an object, or other things, including literary works. Producing literary works also needs to be creative, without creativity it will not create artworks. (Dibia, 2018: 04)

Literary work is also a cultural product made by a writer, and of course, this literary work is interesting to discuss. The formation of literary works is not always purely from one's own thoughts or appreciation but it can be from preexisting texts. Writing literary works can also raise historical facts or events, therefore literary works can be seen chronologically or elevate history (Perdana, 2017). Not only that, there are feelings, ideas, enthusiasm, and beliefs in literary works that are depicted concretely (Kusuma, 2018). With these three things, readers will be amazed.
As a literary work in the form of a novel, it is a series of stories and events orderly and presenting the characters in the story. The novel is also a long story, they cannot be read in one sitting, the nature of the novel is fictional or non-fictional (Samsudin, 2016: 76). By literary works in the form of novels makes readers discover differences and similarities from one another. Therefore, an intertextual study is needed to examine these similarities and differences. Literary works can be known whether the literary work is influenced by other literary works or not, it can be found by comparing literary works with different periods.

Intertextual is an interactive relationship between one text and another (Samsuddin, 2016: 8). Literary works that have an intertextual relationship are not only novels with novels, but also short stories with short stories, poetry with poetry, or short stories with paintings, novels with films, etc. 
The approach taken by intertextual studies is natural; it cannot be done without insight into previous religion and history (Leene, 2014: 12). Producing literary works does not start from a cultural or historical void or community tradition. History is not an object, but an event that is mediated within the horizon of the expectations of contemporary literary experience and the readers, critics, and future writers (Stahlberg, 2008: 18). Intertextual is done with an analytical framework on a text. The text at this point is a text that is carefully studied which will become the data for the study. Intertextual texts and signs do not refer to the world or to the concepts. But it refers to other texts or other signs (Leene, 2000: 115)

Intertextual is a literary study that emphasizes the similarities between the two different novels. The novel has similarities, for example, the theme, characterization, setting, plot, and meaning related to the author's intentions. Intertextual studies emphasize comparative literature by using these studies to find the hypogram and transformation. Hyprograms are taken from texts which may be in the form of words, sigma, form models, ideas, or various other intrinsic elements. (Samsudin, 2016: 11). Meanwhile, transformation is a literary work that has references to create new literary works.

Hypogram is an attempt to find differences and similarities between one text and another. Hypograms are not perfect, but they are partial in the form of text signs or the actualization of certain elements into a certain form. After the reader finds the elements of the hypogram, then he creates a new work.

The new literary work at this point is a transformation from previous works. From the previous works, a hypogram was found, namely the similarity in terms of its intrinsic elements, and then the creation of new literary works called transformations from old literary works.

The novels used as source data were Novel Bumi Manusia by Pramodya Ananta Toer and Novel Sang Raja by Iksa Banu. Bumi Manusia was a novel that is popular among teenagers. The novel had an interesting story, told about a native's struggle to defend his rights from the colonialists in the colonial period. This story was made into a film in 2019. Also, the adding insight to the current generation, many lessons could be taken from the story. Likewise in Novel Sang Raja by Iksaka Banu, was a novel that told about a native's struggle to defend his company during the colonial period.

Novel Bumi Manusia was the first novel and became a hypogram, while Novel Sang Raja was the novel after it and became its transformation. Both novels have differences and similarities in terms of their intrinsic elements.
These forming elements are related to one another. These elements will be meaningful if they have a relation to the whole story. Conversely, if one element is not related, it will have no meaning at all. These intrinsic elements include elements of the theme of the story, plot, setting, characterization, points of view, language style, and mandate (Dibia, 2018: 102)

Based on the description above, how both novels have similarities, namely Novel Bumi Manusia by Pramodya Ananta Toer and Novel Sang Raja by Iksaka Banu on the elements of theme, characterization, and setting. This study aimed to describe and explain how the intertextual Novel Bumi Manusia as a hypogram and Sang Raja became its transformation.

\section{METHOD}

In this study, the researcher used a descriptive method. The descriptive method is to analyze the data into words or sentences instead of numbers. The qualitative method is a research method based on postpositivism or interpretive philosophy, used to examine the condition of a natural object, where the researcher is the key instrument (Sugiyono, 2018: 9). Qualitative research analyzes data based on repeated field data findings, analyzed to find findings that can be arranged according to certain themes. The data source in this study used novel Bumi Manusia by Pramodya Ananta Toer and Sang Raja by Iksaka Banu. The data required are in the form of quotations from novels, sentences, words, or texts from Novel Bumi Manusia and Sang Raja.

Data collection can be done in natural conditions, primary data sources, and data collection techniques using notetaking and documentation techniques (Sugiyono, 2018: 105). The data collection techniques used note-taking and documentary techniques, which were done by reading a novel and documenting every quote or sentence in the text to be used as data of the research. Data analysis technique was analyzed with qualitative technique. The researcher analyzed the data that had been obtained using sentences instead of numbers. Therefore, the analysis in this method was inductive based on the facts found, then it could be constructed into a hypothesis or theory. Data validation technique used observer's persistence technique by conducting research in detail, carefully, and more thoroughly. The validity of the data was also carried out on an ongoing basis to obtain more accurate results from the results of the data that had been analyzed. The second tecnique, triangulation, was done with several views to check the data that had been analyzed to acquire the accurate conclusion. 


\section{RESULTS AND DISCUSSION}

Based on the explanation above, this research conveyed the hypogram and transformation of Novel Bumi Manusia by Pramodya Ananta Toer and Sang Raja by Iksaka Banu by discussing three main problems in the three intrinsic elements, namely theme, characterization, and setting.

Through the results of the analysis on both novels and could be described intertextually. In the intertextual study of Novel Bumi Manusia by Pamodya Ananta Toer and Sang Raja by Iksaka Banu, it focused on three intrinsic elements (a) theme, (b) characterization, and (c) setting. The first analysis was about the theme. The themes raised by both novels were equally in the Dutch colonial period. This theme was also accompanied by minor themes such as the theme of struggle. Novel Bumi Manusia told about a boy of Javanese descent's struggle to fight for his wife from the White court. Novel Sang Raja told about a kretek cigarette entrepreneur's struggle to face various problems.

Hypograms and transformations of themes in novel Bumi Manusia by Pramodya Ananta Toer and Sang Raja by Iksaka Banu

The first analysis in this research was in both themes of the novel. Both novels used the same theme; they used themes during the colonial period in the 20s. It told about the struggle of the main character in the novel Bumi Manusia by Pramodya Ananta Toer and Sang Raja by Iksaka Banu to defend their rights. It could be seen from the quotations of Novel Bumi Manusia and Sang Raja as follows.

"We're going to fight together, Mom."

"Even without lawyers. We'll be the first natives to fight the White Court, Nyo. Isn't that an honor too?"

"I don't understand how to fight, what to fight, who and how. I don't know what tools it has. Even so, we fight" (Pramodya, 2005: 494)

"Our factory was occupied. It was used in military headquarters. The factory operational transportations were confiscated. Dozens of trucks were turned into military transportation. And the most annoying thing was that all the iron properties were moved to the Langgardalem factory and to Mr. Nitisemito's family house because the office in Jongenstraat was also confiscated by the Japanese." (Iksaka, 2017: 327)

Both quotes told about the struggle in the colonial era. Novel Bumi Manusia told about their struggles during the Dutch colonial period. The main character, Minke, was fighting for his wife, Annelies. Annelies was Nyai Ontosoroh's daughter, a native and the Netherlands, Mr. Mellema. Minke fought for Annelies from the White Court who would bring his wife to the Netherland because
Aneelies was born from an illegal marriage and had European blood.

Meanwhile, in novel Sang Raja, it told about the struggle to maintain the production of kretek cigarettes called Bal Tiga during the Japanese occupation. The factory which for years was the production of Bal Tiga cigarette was suddenly confiscated by the Japanese army for military headquarters. Finally, Bal Tiga cigarette production was moved to Langgardalem in order to stay producing. Although both novels had different stories, there were similarities and there was intertextuality of the novel in terms of themes. So, the novel Sang Raja had a hypogram in the novel Bumi Manusia.

\section{Hypograms and transformations of the characterization in novel Bumi Manusia and Sang Raja}

The second analysis was about the characters and figures of the novel Bumi Manusia and Sang Raja. The main characters in both novels had similarities in terms of origins and character traits. So that, from the equation of both novels there was an intertextual relationship. The quotations from both novels were as follows.

"This kris was used by all your ancestors except your father. This kris was provided by your Nendamu for you, Gus. Ah, how should I talk to you?" (Pramodya, 2005: 462)

"Nitisemito was a son of the village head. His first name, Roesdi bin Soelaiman. Although he was blueblooded, it was said that he was illiterate because he had never got a formal education."(Iksaka, 2017: 104)

From these quotations, it could be seen that the main character of both novels had the same background, which was, both of them were of Priyayi (means: elite people) descent. It was clear from the first quote in the novel Bumi Manusia, Gus's call to Minke showed the nickname that Javanese always use to priyayi descendants for boys. The word kris is an object that is owned by Javanese people of royal descent. In the second quote, the character Nitisemito was the son of the village head. Niti was not only the son of the village head, but he was a priyayi descent, who stated that Nitisemito was blue-blooded. Blue-blooded means a descent of the nobility or the Javanese kingdom. The quote had similarities from the background of the same figures from the Priyayi circle.

"Furniture of the top class, Mom," I began to propaganda "from the latest European style and mode. Usually I offered it on the ship to newcomers, as well as at the homes of my school friends' parents." (Pramodya, 2005: 58)

"Nitisemito tries to market his cigarettes in packages with a specific name and tag. He tried several times 
until he finally found a picture of this triple circle." (Iksaka, 2017: 110)

In both quotes above, it explained that the character of the main character in novel Bumi Manusia and Sang Raja, both of them were hardworking and persistent characters. It could be seen clearly from the way the two main characters try to market their field. Based on the above quotation, the first quote had similarities to the second quote. Thus, it could be proven that the novel Bumi Manusia had a hypogram text and Sang Raja became its transformation text.

As for additional characters that showed similarities in the story, it could be seen from the following quote.

"The company we have worked hard could be collapse vainly. It is everything our life hitches on." (Pramodya, 2005: 150)

"But Hotel Gordel van Smaragd is going through its most prosperous period this year under the leadership of Walini.” (Iksaka, 2017: 148)

In both quotes above, it was shown that the characteristics of the two additional figures which had the same character. Both of them had hardworking character. In the novel Bumi Manusia, Nyai Ontosoroh continued her husband's business as a farmer. Meanwhile, in the novel Sang Raja, the character Walini continued her husband's efforts to take care of the hotel, the legacy of his parents. Other additional figures which had similarities in terms of characterization were as follows

\begin{abstract}
"Based on official letters from Surabaya which could not be doubted its truth, the decision regarding all properties of the late Mr. Herman Mellema was to be later because there was no legal marriage relationship between Mr. Herman Mellema and Sanikem." (Pramodya, 2005: 485)

"It makes sense if Akoean Markoem is included in Nasilah's choice as the main heir. Akoean Markoem is his real grandson, the son of Nahari's marriage and the late Haji Markoem. In Akoean Markoem's body flows Nitisemito's blood.” (Iksaka, 2017: 235)
\end{abstract}

Based on the story above, there was an additional figure which had the same characteristics between the novel Bumi Manusia and Sang Raja. Maurits Mellema was the first child of Mr. Mellema and Mevrouw Amelia Mellema Hammers from a legal marriage who wanted all of $\mathrm{Mr}$. Mellema's property. Hypogrammed with the figures in the novel Sang Raja, Nasilah was Nitisemito's first wife, who legitimately wanted his grandson Akoean Markoem to become the main heir of the company, because Akoean Markoem has Nitisemito's blood. In this problem, it could be proven that the novel Bumi Manusia was a hypogram text, and Sang Raja was a text for its transformation.

\section{Hypogram and transformation of setting in novel Bumi Manusia and Sang Raja}

The third intertextual analysis was the setting that occurred in the novel Bumi Manusia and Sang Raja. The two novels had different plots, the plot in the novel Bumi Manusia used a forward plot, while in novel Sang Raja used a back and forth plot. But in the setting, those novels had similarities in one situation as in the following quote.

"In my hands now there is a decision from the Surabaya Court for Jeffrouw Annelies Mellema, the son of the late Mr. Herman Mellema. According to the decision, Juffrouw Annelies Mellema will be transported by ship from Surabaya in the next five days." (Pramodya, 2005: 533)

"With yelling and coercion, Mr. Pollman and Philip were dragged forward by two soldiers, and their legs were bent so that both fell to their knees." (Iksaka, 2017: 301)

In those quotes above was the setting that occurred in the novel Bumi Manusia and Sang Raja, the problems in both novels had similar setting. The situation depicted in the quote above was sadness.

In the novel Bumi Manusia, sadness was seen in the main character when he heard the decision from the court that Annelies would be brought to Europe by the ship that would come in five days. The sadness in the novel Bumi Manusia was hypogrammed with the sadness experienced by the main character in the novel Sang Raja. In the novel Sang Raja, sadness occured to Nitisemito who was sad while the Japanese suddenly attacked Philip and Mr. Pollman and took him forcibly.

\section{CONCLUSION}

The results of the analysis and discussion on intertextual research on the novel showed that the novel Sang Raja had a hypogram in the novel Bumi Manusia. It was clear from the results of the analysis that emphasized the elements of theme, characterization, and setting. The intertextual relationship could be seen clearly in the analysis of the theme of the novel Bumi Manusia and Sang Raja both novels used the same theme, namely the theme of struggle in the colonial era. Furthermore, intertextual was also seen in the setting of the main character, both of them had the same background, namely from priyayi circle. The characters of the main characters also had something in common; both of them had a hardworking character. The same characterization was also evident in the additional figures of Nyai 
Ontosoroh and Walini, both of them were hard worker. Meanwhile, Maurits Mellema and Nasilah also had the same character, wanted to control the company. The third analysis was on the setting of the situation, the two novels had the same situation, namely the sadness experienced by the main character when they saw loved ones who had to be carried forcibly. So it could be proven that Novel Bumi Manusia by Pramodya Ananta Toer was a hypogram text, while novel Sang Raja was its transformation text.

\section{REFERENCES}

[1] Dibia, I Ketut. 2018. Apresiasi Bahasa dan Sastra Indonesia. Depok: RajaGrafindo Persada.

[2] Perdana, Dean, Dkk. 2017. Intertekstualitas dalam Novel Tembang Cinta Bumi Sunda Karya Aan Merdeka Permana dengan Novel Gajah Mada Perang Bubat Karya Langit Kresna Hariadi. Jurnal Sastra Indonesia. Vol. 6 (1). Hlm 8.

[3] Kusuma, Krisna Aji, Dkk. 2018. Pengakuan Calabai: Sebuah Analisis Intertekstual Novel Pasung Jiwa Karya Okky Madasari Dan Novel Calabai Karya Pepi AlBayqunie. Jurnal Kata. Vol. 2 (1). Hlm 53-61.

[4] Samsudin. 2016. Pengkajian Prosa fiksi berbasis teori intertekstual. Yogyakarta: Deepublish.

[5] Leene, Henk. 2014. Newness in Old Testament Prophecy An Intertextual Study. Netherlands: Koninklijke Brill NV.

[6] Stahlberg, Lesleigh Cushing. 2008. Sustaining fictions : Intertextuality, Midrash, Translation, And The Literary Afterlife Of The Bible. New York: $\mathrm{T} \& \mathrm{~T}$ Clark International.

[7] Sugiyono. 2018. Metode Penelitian Kualitatif. Bandung: Alfabeta. 